\title{
Раціональне лікування небактеріальних та бактеріальних інфекцій верхніх дихальних шляхів у рамках проблеми стримування зростання бактеріальної резистентності
}

Сьогодні, в епоху доказової медицини, досить складно усвідомити деякі процеси, що відбуваються, адже навіть фармацевтичні компанії, які виробляють антибіотики, виступають за те, щоб лікарі не призначали антибактеріальні препарати тою мірою, в якій вони їх призначають. Чому так відбувається?

Сукупність понять, які характеризують розвиток медичної науки, постійно змінюється. Спочатку медицина була архаїчною, потім народною (ми й дотепер маємо ці прояви у повсякденному житті). Потім настав етап наукової, класичної, так званої гіппократівської медицини, представниками якої є й сучасні лікарі. Наразі етап доказової медицини. Якщо гіппократівська медицина - це медицина одного «п», то сучасна доказова - чотирьох «п». В основі класичної медицини одного «п» - практицизм (прагматичність) - зосередження уваги на практичній діяльності та нехтування значенням теорії. Концептуальною основою сучасної медицини чотирьох «П» $:$

- предиктивність (оцінювання імовірності тієї чи іншої патології у конкретної особи, прогноз ефективності того чи іншого лікування: якщо препарат призначено не за показаннями, неможливо прогнозувати його ефективність);

- профілактичність (методи, що дозволяють запобігти, зменшити, контролювати ризики розвитку чи прогресування захворювання, тобто превентивна медицина);

- персоніфікованість (ідентифікація індивідуальних особливостей розвитку захворювання та на їх основі - індивідуалізація лікувального процесу);

- партисипативність (співпраця медиків і пацієнта, участь пацієнта уприйнятті усіх медичних рішень як запорука успіху лікування).

Необхідно пам'ятати, що антибіотики слід призначати лише за показаннями. Саме це завдання виконує сучасна медицина чотирьох «п». Але, на жаль, сьогодні картина призначень антибіотиків оториноларингологами, терапевтами (сімейними лікарями)

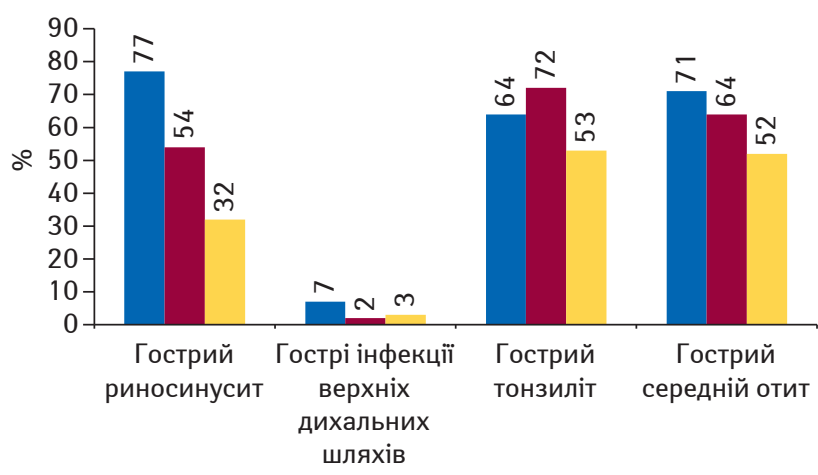

- Оториноларингологи — Терапевти (сімейні лікарі) Педіатри

Рис. 1. Частка призначень антибіотиків за нозологіями за спеціальностями у 2018 р. Дані аналітичної системи Pharmstandart за 2017 р., 25 міст (http:// www.pharmstandart.com.ua) та педіатрами при таких поширених захворюваннях, як гострий риносинусит, гострі інфекції верхніх дихальних шляхів, гострий тонзиліт, гострий середній отит, виглядає таким чином, як показано на рис. 1. Це при тому, що максимум 10\% пацієнтів потребують антибактеріальної терапії у разі вищезазначених нозологій.

Інструментами медицини чотирьох «П» в оториноларингології $€$ клінічні рекомендації, які є зведенням найкращих клінічних практик:

- Наказ Міністерства охорони здоров'я (МО3) України від 16.07.2014 р. № 499 «Про затвердження та впровадження медико-технологічних документів зі стандартизації медичної допомоги при грипі та гострих респіраторних інфекціях».

- Наказ МОЗ України від 11.02.2016 р. № 85 «Про затвердження та впровадження медико-технологічних документів зі стандартизації медичної допомоги при гострих запальних захворюваннях верхніх дихальних шляхів та вуха».

- наказ МОЗ України від 28.12.2016 р. № 1422 «Про внесення змін до наказу Міністерства охорони здоров'я України від 28 вересня 2012 р. № 751 ».

Нагадаємо, що, згідно з Уніфікованим клінічним протоколом «Гострі респіраторні інфекції», затвердженим наказом МОЗ України від 16.07.2014 р. № 499 (у редакції наказу МО3 України від 11.02.2016 р. № 85), діагноз «гостра респіраторна інфекція» передбачає визначення:

- J00 гострий назофарингіт (нежить)

- J02 гострий фарингіт

- J02.9 гострий фарингіт неуточнений

- J03 гострий тонзиліт

- J03.9 гострий тонзиліт неуточнений

- J04 гострий ларингіт і трахеїт

- J04.0 гострий ларингіт

- J04. 1 гострий трахеїт

- J04.2 гострий ларинготрахеїт

- J06 гострі інфекції верхніх дихальних шляхів множинних або неуточнених локалізацій

У разі відповідності клінічної картини гострої респіраторної інфекції критеріям гострого риносинуситу медична допомога надається згідно з Уніфікованим клінічним протоколом «Гострий риносинусит».

\section{Гострий риносинусит}

Клінічні діагностичні критерії гострого риносинуситу представлені в табл. 1.

Важливо пам'ятати, що у зв'язку з багатофакторністю етіопатогенезу гострого риносинуситу немає доведеної ефективності будь-якої монотерапії - як системної, так і місцевої. Запорука успіху - комплексна терапія, спрямована на основні ланки етіопатогенезу захворювання (набряк, запалення, порушення реології секрету, імунодефіцит). Останній у пацієнтів із гострим риносинуситом пов'язаний із зупинкою мукоциліарного транспорту. Тож для правильного лікування потрібно впливати на ці ланки патогенезу (рис. 2). 
Таблиця 1. Клінічні діагностичні критерії гострого риносинуситу

\begin{tabular}{|c|c|c|c|}
\hline \multirow{2}{*}{ Нозологічна одиниця } & \multirow{2}{*}{ Визначення } & \multicolumn{2}{|c|}{ Симптоми/ознаки } \\
\hline & & Великі (основні) & Малі (додаткові) \\
\hline \multirow[t]{2}{*}{ Гострий риносинусит } & Раптова поява $\geqslant 2$ симптомів, один з яких належить до великих & \multirow{4}{*}{$\begin{array}{l}\text { · закладеність/обструкція носа; } \\
\text { • виділення з носа (переднє } \\
\text { чи заднє затікання) }\end{array}$} & \\
\hline & Симптомів & & • біль та/чи відчуття тиску \\
\hline Гострий вірусний риносинусит & $\begin{array}{l}\text { Гострий риносинусит тривалістю <10 днів за умови відсутності } \\
\text { погіршення симптомів після 5-го дня від початку захворювання }\end{array}$ & & $\begin{array}{l}\text { в проекції приносових пазух; } \\
\text { • зниження або втрата нюху; }\end{array}$ \\
\hline \multirow{2}{*}{$\begin{array}{l}\text { Гострий поствірусний } \\
\text { риносинусит } \\
\text { Гострий бактеріальний }\end{array}$} & $\begin{array}{l}\text { Погіршення симптомів після 5-го дня від початку захворювання } \\
\text { або стійкість симптомів після 10-го дня від початку захворювання }\end{array}$ & & • кашель (особливо у дітей) \\
\hline & Наявність щонайменше 3 із нижченаведених симптомів/ознак & \multirow{5}{*}{\multicolumn{2}{|c|}{$\begin{array}{l}\text { • виділення з порожнини носа (переважно з одного боку) } \\
\text { і одночасна наявність слизових чи гнійних виділень у носовій } \\
\text { порожнині (при риноскопії); } \\
\text { • двофазність захворювання (погіршення після першої, легшої, } \\
\text { фази захворювання); } \\
\text { • значний локальний біль (переважно однобічний); } \\
\text { • лихоманка (>38 드) }\end{array}$}} \\
\hline \multirow{4}{*}{ риносинусит } & & & \\
\hline & & & \\
\hline & & & \\
\hline & & & \\
\hline
\end{tabular}

Сьогодні найсучасніша технологія лікування пацієнтів із гострим риносинуситом - так званий фізіологічний підхід. Основна мета лікування при гострому риносинуситі - вплив на слизову оболонку носового ходу і відновлення функції остіомеатального комплексу, куди відкриваються співустя практично усіх пазух.

Препарати, ефективність яких доведена згідно з вимогами доказової медицини, представлені в табл. 2.

\section{Гострий тонзиліт}

Клінічні діагностичні критерії гострого тонзиліту наведені в табл. 3.

Етіопатогенетичне обґрунтування фізіологічного терапевтичного підходу при гострому тонзиліті представлено на рис. 3 .

Згідно з Міжнародною класифікацією хвороб 10-го перегляду виокремлюють:

- J03.0 Стрептококовий тонзиліт

- J03.8 Гострий тонзиліт, викликаний іншими збудниками

\begin{tabular}{|c|c|c|}
\hline $\begin{array}{l}\text { Антибактеріальний } \\
\text { Противірусний }\end{array}$ & 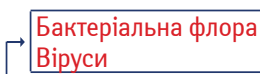 & $\begin{array}{l}\text { Етіотропні препарати } \\
\text { за правилами }\end{array}$ \\
\hline $\begin{array}{l}\text { Протинабряковий } \\
\text { Протизапальний }\end{array}$ & $\rightarrow \begin{array}{l}\text { Набряк } \\
\text { Запалення }\end{array}$ & $4 \begin{array}{l}\text { Комплекс моноспря- } \\
\text { мованих препаратів }\end{array}$ \\
\hline $\begin{array}{l}\text { Секретолітичний } \\
\text { Секретомоторний }\end{array}$ & $\rightarrow \begin{array}{l}\text { Порушення реології } \\
\text { секрету }\end{array}$ & $\dashv$ з комплексною дією \\
\hline Імуномодулюючий & $\rightarrow$ Імунодефіцит & \\
\hline
\end{tabular}

Рис. 2. Комплексна, етіопатогенетично обґрунтована терапія гострого риносинуситу

Таблиця 2. Лікування у разі гострого риносинуситу за принципами доказової медицини

\begin{tabular}{|c|c|}
\hline Лікування & Рекомендації \\
\hline Антибіотики & $\begin{array}{l}\text { Так (лише при гострому бактеріальному } \\
\text { риносинуситі) }\end{array}$ \\
\hline Топічні кортикостероїди & Так (лише при післявірусному риносинуситі) \\
\hline Топічні кортикостероїди & Так (лише при гострому бактеріальному \\
\hline $\begin{array}{l}\text { в поєднанні з антибіотиками } \\
\text { Системні кортикостероїди }\end{array}$ & риносинуситі) \\
\hline $\begin{array}{l}\text { в поєднанні з антибіотиками } \\
\text { Іригаційна терапія }\end{array}$ & $\begin{array}{l}\text { Так (як симптоматична терапія при всіх } \\
\text { формах гострого риносинуситу) }\end{array}$ \\
\hline $\begin{array}{l}\text { Фітотерапія } \\
\text { Нестероїдні протизапальні препарати } \\
\text { Парацетамол }\end{array}$ & $\begin{array}{l}\text { Так (при вірусному та післявірусному } \\
\text { риносинуситі) }\end{array}$ \\
\hline
\end{tabular}

Таблиця 3. Клінічні діагностичні критерії гострого тонзиліту

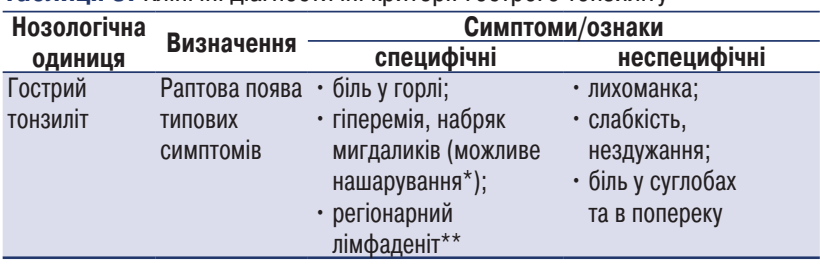

*Нашарування не є патогномонічним симптомом гострого тонзиліту взагалі, тим більше бактеріального. Вони можуть бути наявні у деяких хворих, але відомо досить багато клінічних ситуацій наявності нашарувань за відсутності тонзиліту. *^Регіонарний лімфаденіт у пацієнта з тонзилітом, специфічний у ділянці защелепного лімфовузла (з кутом нижньо щелепи і мочкою вуха).

- J03.9 Гострий тонзиліт неуточнений

Як же у клінічній практиці відрізнити стрептококовий тонзиліт від нестрептококового? Адже це принципово важливо при вирішенні питання щодо призначення чи непризначення антибіотика. Для цього існує шкала Mclsaac, яку використовують для пацієнтів із болем у горлі без гострої задишки (Mclsaac W.J. et al., 1998) (табл. 4). На рис. 4 показано, як трактувати її результати.

Таким чином, антибіотики - це етіотропне лікування, і для того, щоб воно подіяло, повинна бути причина - мікроорганізми. При обґрунтуванні фармакотерапії запальних процесів лОРорганів принципово важливим $€$ положення про те, що в їх основі має бути саме бактеріальна інфекція і пов'язана з нею тяжкість перебігу захворювання.

\section{Гострий тонзиліт}

\section{$\downarrow$}

Спричинений патогенами запальний процес (альтерація тканин мигдалика)

$$
\downarrow
$$

Адекватна імунологічна реактивність $\rightarrow$ «фагоцитоз" $\rightarrow+$ антибіотики

(при показаннях) елімінація патогена $\rightarrow$ контроль над запаленням

\section{$\downarrow$}

Реституція (одужання)
Спотворення імунологічної реактивності + неадекватна антибіотикотерапія $\rightarrow$ "незавершений фагоцитоз" $\rightarrow$ неможливість елімінації патогенів $\rightarrow$ «персистуюче запалення понад фізіологічне» $\downarrow$

Клінічні ознаки рекурентного тонзиліту

Рис. 3. Етіопатогенетичне обґрунтування фізіологічного терапевтичного підходу при гострому тонзиліті

\section{Таблиця 4. Шкала Mclsaac}

\begin{tabular}{|c|c|}
\hline Симптом & Бал \\
\hline Температура тіла $>38^{\circ} \mathrm{C}$ & 1 \\
\hline Відсутність кашлю & 1 \\
\hline Збільшення шийних лімфатичних вузлів & 1 \\
\hline Збільшення чи нашарування на мигдаликах & 1 \\
\hline \multicolumn{2}{|l|}{ Вік, років } \\
\hline $3-14$ & 1 \\
\hline $15-44$ & 0 \\
\hline$\geqslant 45$ & -1 \\
\hline \multicolumn{2}{|l|}{ Сума балів за шкалою Mclsaac } \\
\hline$\downarrow$ & \\
\hline $1-3$ & \\
\hline
\end{tabular}

- Висока ймовірність

бактеріального тонзиліту

При підозрі на бактеріаль-

ний тонзиліт - мазок

із зіва на мікробіологічну

культуру, бактеріоскопічне

дослідження чи експрес-

тест

\section{$\downarrow$}

- Висока ймовірність вірусного тонзиліту - За умови сприятливого самостійного перебігу обстеження не потрібне

- За умови відсутності покращення, значної тяжкості хвороби чи однобічного ураження - бактеріоскопічне та бактеріологічне обстеження
Рекомендована терапія нестероїдними протизапальними препаратами протягом 2-3 днів

При виявленні або серйозній підозрі на стрептококовий тонзиліт антибіотикотерапія

Рис. 4. Тактика лікаря залежно від суми балів за шкалою Mclsaac 


\section{ДИСТАНЦИЙНЕ НАВЧАННЯ}

Таблиця 5. Алгоритм антибактеріальної терапії

\begin{tabular}{|c|c|c|}
\hline $\begin{array}{c}\text { Захищені } \\
\text { амінопеніциліни }\end{array}$ & $\begin{array}{c}\text { Незахищені } \\
\text { амінопеніциліни }\end{array}$ & Цефалоспорини III покоління \\
\hline$\downarrow$ & $\downarrow$ & $\downarrow$ \\
\hline $\begin{array}{l}\text { Препарати вибору } \\
\text { для стартової } \\
\text { терапії гострого } \\
\text { бактеріального } \\
\text { риносинуситу } \\
\text { у стандартних } \\
\text { клінічних ситуаціях }\end{array}$ & $\begin{array}{l}\text { Препарати вибору } \\
\text { для стартової } \\
\text { терапії гострого } \\
\text { бактеріального } \\
\text { тонзиліту } \\
\text { у стандартних } \\
\text { клінічних ситуаціях }\end{array}$ & $\begin{array}{l}\text { - обґрунтована підозра на грамнега- } \\
\text { тивний характер мікрофлори: } \\
\text { нозокоміальні процеси (крім } \\
\text { Pseudomonas aeruginosa, } \\
\text { метицилінрезистентний } \\
\text { Staphylococcus aureus); } \\
\text { • ускладнений перебіг (менінгіт, } \\
\text { ендокардит); } \\
\text { - отит, кон'юнктивіт; } \\
\text { • застосування амінопеніцилінів } \\
\text { протягом останніх <3 міс }\end{array}$ \\
\hline & & $\downarrow$ \\
\hline
\end{tabular}

Рецидивуючий перебіг гострого риносинуситу, гострого середнього отиту, гострого тонзиліту в анамнезі не $€$ ознакою бактеріальної етіології захворювання і не $є$ показанням для призначення антибактеріальних препаратів

Згідно з наказом МОЗ України від 16.07.2014 р. № 499, існують переваги відкладеного призначення антибіотика порівняно зі стратегією відмови від його призначення. Основною умовою вибору стратегії відкладеного призначення антибіотиків $€$ не пасивне спостереження пацієнта, а призначення лікування з доведеною ефективністю відповідно до встановленого діагнозу.
Алгоритм антибактеріальної терапії представлений у табл. 5. Важливо також пам'ятати, що антибіотики не впливають на біль, і навіть після 3-7 днів антибактеріальної терапії постійний біль відзначають у $30 \%$ дітей.

Доцільність місцевого застосування антибіотиків сумнівна, оскільки вони не потрапляють у порожнини носа й пазухи, із порожнини рота чи глотки в лакуни мигдаликів, через неперфоровану барабанну перетинку до порожнини середнього вуха.

\section{Список використаної літератури}

м03 України (2014) Наказ М03 України від 16.07.2014 р. № 499 «Про затвердження та впровадження медико-технологічних документів зі стандартизації медичної допомоги при грипі та гострих респіраторних інфекціях» (http://old. moz.gov.ua/ua/portal/dn 20140716 0499.html).

м03 України (2016) Наказ М03 України від 11.02.2016 р. № 85 «Про затвердження та впровадження медико-технологічних документів зі стандартизації медичної допомоги при гострих запальних захворюваннях верхніх дихальних шляхів та вуха» (http://old.moz.gov.ua/ua/portal/dn_20160211 0085.html).

м03 України (2016) Наказ МОЗ України від 28.12.2016 р. № 1422 «Про внесення змін до наказу Міністерства охорони здоров'я України від 28 вересня 2012 року № 751» (http://old.moz.gov.ua/ua/portal/dn 20161229 1422.html).

Mclsaac W.J., White D., Tannenbaum D., Low D.E. (1998) A clinical score to reduce unnecessary antibiotic use in patients with sore throat. CMAJ, 158(1): 75-83.

Інформація для спеціалістів сфери охорони здоров'я 6-01-МЕД-РЕЦ-1219 
1. Відповідно до сучасних положень щодо лікування пацієнтів ЛОР-профілю, антибіотикотерапію:

- слід призначати лише у тих клінічних випадках, де наявні чіткі показання на те

- можна призначати з профілактичною метою

- можна призначати за відсутності на те чітких показань у тому разі, якщо пацієнт наполягає на їі призначенні

\section{2. Дайте визначення гострого риносинуситу:}

- гострий перебіг риносинуситу тривалістю <10 днів за умови відсутності погіршення симптомів після 5-го дня від початку захворювання

- раптова поява $\geqslant 2$ симптомів, один з яких належить до великих симптомів

- погіршення симптомів після 5-го дня від початку захворювання або стійкість симптомів після 10-го дня від початку захворювання

\section{3. Для встановлення діагнозу «гострий} бактеріальний риносинусит" потрібна наявність щонайменше трьох із наведених симптомів/ознак:

- закладеність/обструкція носа

- виділення з порожнини носа (переважно з одного боку) і одночасна наявність слизових чи гнійних виділень у носовій порожнині (при риноскопії)

- двофазність захворювання (погіршення після першої, легшої, фази захворювання)

- зниження чи втрата нюху

- значний локальний біль (переважно однобічний)

- лихоманка $\left(>38^{\circ} \mathrm{C}\right)$

- кашель (особливо у дітей)

\section{4. Чи слід призначати антибіотики} при гострому риносинуситі згідно

з рекомендаціями, заснованими на даних доказової медицини?

- так (лише при післявірусному риносинуситі)

- так (лише при гострому бактеріальному риносинуситі)

- так (при всіх формах гострого риносинуситу)

\section{5. До специфічних симптомів гострого} тонзиліту відносять:

- лихоманку
- біль у горлі

- гіперемію, набряк мигдаликів (можливе нашарування)

- регіонарний лімфаденіт

- слабкість, нездужання

- біль у суглобах та в попереку

6. Пацієнтка Б., 14 років. Скарги на підвищення температури тіла до $39^{\circ} \mathrm{C}$, нежить, біль у горлі. При огляді - збільшення шийних лімфатичних вузлів, збільшення та нашарування на мигдаликах. Виставлено діагноз "лакунарна ангіна". Чи показаний антибіотик у цьому клінічному випадку? - так

- $\mathrm{Hi}$

7. Пацієнт В. , 40 років. Скарги на утруднене носове дихання, закладеність носа, виділення з носа, головний біль. Хворіє протягом 2 тиж. При огляді - набряк та гіперемія слизової оболонки носа, виділення слизисто-гнійні, дихання носом утруднене. Встановлено діагноз "гострий бактеріальний риносинусит». Чи показаний антибіотик у цьому клінічному випадку?

- так

- $\mathrm{Hi}$

8. Препаратами вибору для стартової терапії при гострому бактеріальному риносинуситі

у стандартних клінічних ситуаціях є:

- захищені амінопеніциліни

- незахищені амінопеніциліни

- цефалоспорини III покоління

- немає правильної відповіді

9. Рецидивуючий перебіг гострого риносинуситу, гострого середнього отиту, гострого тонзиліту в анамнезі:

- $€$ ознакою бактеріальної етіології захворювання

- не є ознакою бактеріальної етіології захворювання

- $є$ показанням для призначення антибактеріальних препаратів - неєпоказанням для призначення антибактеріальнихпрепаратів

Для отримання сертифіката дайте відповідь на тестові запитання в режимі on-line на сайті журналу www.umj.com. ua або надішліть ксерокопію сторінок з відповідями разом з контактною інформацією за адресою: 01001, Київ-1, а/с «В»-82, ТОВ «МОРІОН»

\section{КОНТАКТНІ ДАНI:}

ПІБ

Поштова адреса: індекс

$$
\begin{aligned}
& \text { область } \\
& \text { район } \\
& \text { місто } \\
& \text { вулиця } \\
& \text { будинок } \\
& \text { квартира }
\end{aligned}
$$

Телефон

\section{E-mail}

